\title{
Microspatial Structure of Population Gene Pool in the Land Snail Helicopsis striata (Pulmonata, Hygromiidae) in the Conditions of the Southern Mid-Russian Upland
}

\author{
A. A. Sychev ${ }^{a, *}$ and E. A. Snegin ${ }^{a, * *}$ \\ ${ }^{a}$ Belgorod National Research University, Belgorod, 308015 Russia \\ *e-mail: syvuch20@yandex.ru \\ **e-mailsnegin@bsu.edu.ru
}

Received March 25, 2016; in final form, June 7, 2016

\begin{abstract}
Microspatial differentiation of the population gene pools of the terrestrial mollusk Helicopsis striata (Müller, 1774) is revealed for various conditions of the Southern Mid-Russian Upland, which is caused by the fragmentation of habitats and differences in the intensity of the gene flow between demes. The spatial differentiation of $H$. striata, due to the special features of its biology, is the highest among other terrestrial mollusks of the studied region. Populations with a low variability and weak gene pool differentiation are demonstrated to be the most vulnerable. The methodological importance of the intrapopulation structure of the species is specifically noted for the works on estimating the state of the population's gene pools, since the single datasets of individual demes cannot demonstrate the true nature of the genetic structure of the populations.
\end{abstract}

Keywords: terrestrial mollusk, Helicopsis striata, microspatial genetic structure, Mid-Russian Upland

DOI: $10.1134 / \mathrm{S} 2079059718020107$

\section{INTRODUCTION}

Spatial genetic differentiation is an important marker of the state of natural populations under variable conditions of the environment [21]. For example, with an increase of the biotopic diversity in a population, intrapopulation groups that are stable in space and time (demes or subpopulations) are formed, each of which is adapted to the local conditions [3, 4, 14]. This considerably increases the viability of the population and contributes to its further survival. The appearance of the genetic isolation of demes can be considered a key aspect in the formation of the structure, as that appearance is the direct consequence of a disturbance of panmixia and leads to the temporary stabilization of the intrapopulation structure.

A highly aggregated type of spatial structure and low migratory activity make terrestrial mollusks good model objects for studying intrapopulation structuring [6]. Currently, there are well-known studies of the microspatial genetic structure in mollusks such as Trochoidea geyeri (Soos, 1926) based on RAPD markers [23]; Pomatias elegans (Müller, 1774), based on isozymes [22]; Helix aspersa (Müller, 1774), based on isozymes and microsatellites [16, 17, 24]; and Brephulopsis bidens (Krynicky, 1883), based on the variability of conchological features $[5,19]$. However, many problems of the genetic structuring of the populations of terrestrial mollusks remain unsolved. In particular, one of the most recent trends is to estimate the differentiation of the population's gene pools of the rare and vulnerable mollusk species, which can become an important part of the studies on the conservation and restoration of their populations. In this respect, populations of the xerophilious mollusk Helicopsis striata, which inhabits the rugged landscape of the Southern Mid-Russian Upland and which is protected in Belgorod region in Russia [13].

The aim of the study is to analyze the microspatial differentiation of the genetic structure of $H$. striata populations living in heterogeneous conditions of the Southern Mid-Russian Upland.

\section{MATERIALS AND METHODS}

Studies of the intrapopulation differentiation of the H. striata gene pool were conducted in the autumn of 2011 and 2012. For this purpose, six model populations (Fig. 1) were selected in the Southern Mid-Russian Upland associated with biotopes with different topographic and climatic conditions (Table 1).

In each population of $H$. striata, five experimental sites with an area of $25 \mathrm{~m}^{2}$ each were laid at equal intervals of $150-200 \mathrm{~m}$, within which the individuals were collected. Due to the relatively large distance between the collection points, each site was assumed to corre- 


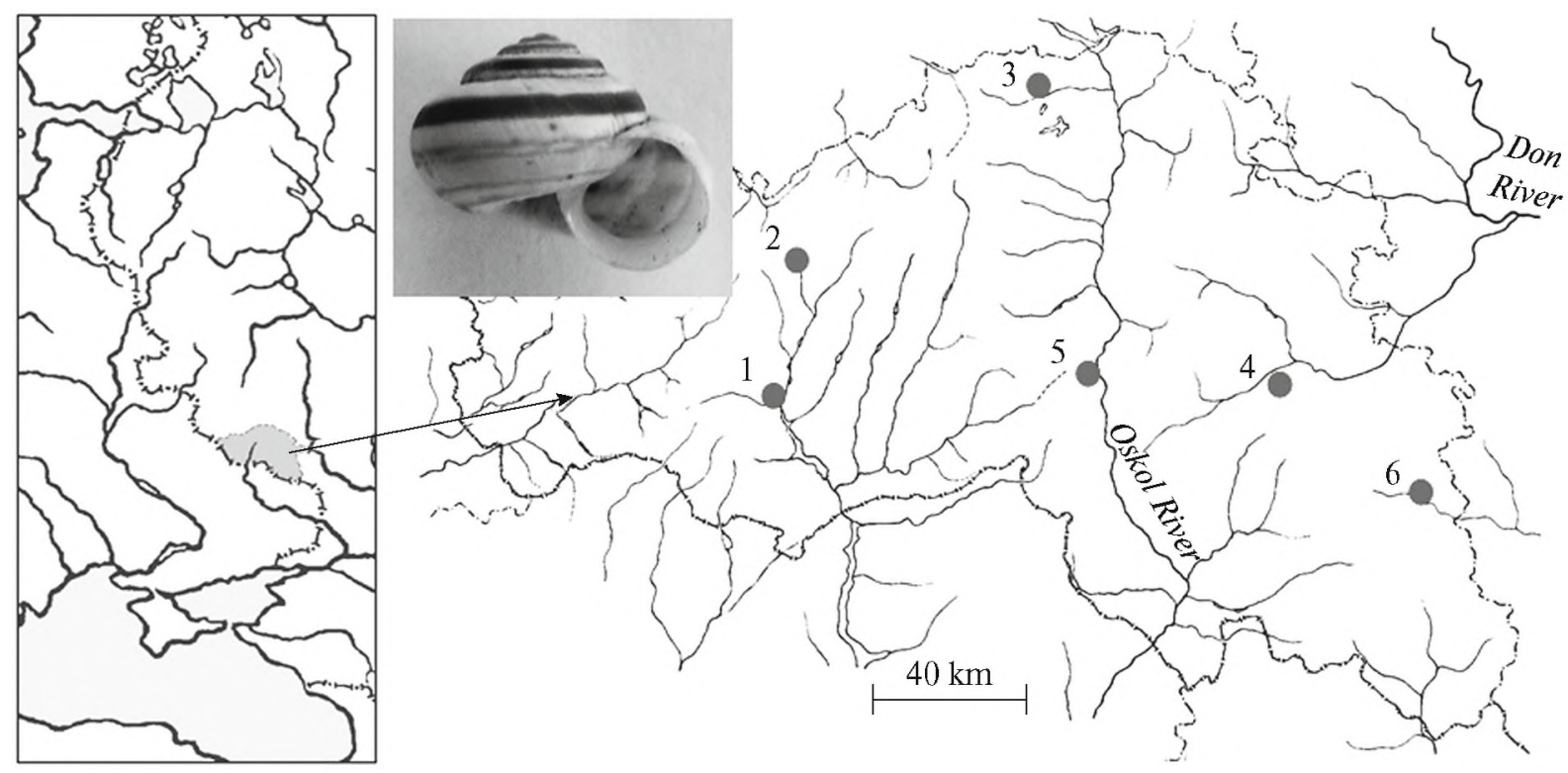

Fig. 1. Location of studied H. striata populations in Southern Mid-Russian Upland: (1) Belaya Gora; (2) Belenikhino; (3) Gubkin; (4) Zasosna; (5) Verkhnye Lubyanki; (6) Osadchee.

spond to a separate deme. Therefore, 30 demes from six populations of $H$. striata were studied.

The isozymes were exctracted from the feet of mollusks. The electrophoresis of isozymes was then con- ducted in $10 \%$ polyacrylamide gel (VE-3 chamber, Helicon). To detect nonspecific esterases, the blocks were stained in the substrate mixture: Tris $\mathrm{HCl}(\mathrm{pH} 7.4)$, $\alpha$-naphthyl acetate, fast red TR; to detect superoxide

Table 1. Description of $H$. striata collection sites

\begin{tabular}{c|c|l}
\hline Population & Coordinates & \multicolumn{1}{c}{ Description } \\
\hline Belaya Gora & $\begin{array}{l}50^{\circ} 37^{\prime} 29.65^{\prime \prime} \mathrm{N} \\
36^{\circ} 37^{\prime} 09.64^{\prime \prime} \mathrm{E}\end{array}$ & $\begin{array}{l}\text { Isolated population (colony) located on steep northwestern bank of Severskii } \\
\text { Donets River in forest-steppe zone. Landscape is highly fragmented due to } \\
\text { natural and anthropogenic processes. Typical calcephyte and dry meadows }\end{array}$ \\
\hline Belenikhino & $\begin{array}{l}50^{\circ} 54^{\prime} 48.11^{\prime \prime} \mathrm{N} \\
36^{\circ} 38^{\prime} 34.49^{\prime \prime} \mathrm{E}\end{array}$ & $\begin{array}{l}\text { Colony located on steep eastern bank of Sazhenskii Donets River in forest- } \\
\text { steppe zone. Landscape highly fragmented with gullies. Common dry meadows, } \\
\text { steppes with calcephyte elements and flora representative of Lower Alps. Pro- } \\
\text { nounced differences between sites }\end{array}$ \\
\hline Gubkin & $\begin{array}{l}51^{\circ} 17^{\prime} 40.59^{\prime \prime} \mathrm{N} \\
37^{\circ} 32^{\prime} 24.21^{\prime \prime} \mathrm{E}\end{array}$ & $\begin{array}{l}\text { Semi-isolated population located on eastern bank of Velikii Kolodez River } \\
\text { (Upper Pooskolye) in forest-steppe zone. Landscape fragmented due to eco- } \\
\text { nomic use. Common feather grass steppes with calcephyte elements and flora } \\
\text { representative of Lower Alps. Pronounced differences between sites }\end{array}$ \\
\hline Verkhnie Lubyanki & $\begin{array}{l}50^{\circ} 37^{\prime} 48.29^{\prime \prime} \mathrm{N} \\
38^{\circ} 25^{\prime} 21.31^{\prime \prime} \mathrm{E}\end{array}$ & $\begin{array}{l}\text { Semi-isolated population located on flat and eroded northern bank of Tikhaya } \\
\text { Sosna River in steppe zone. Typical feather grass steppes and dry meadows with } \\
\text { calcephytes and flora representative of Lower Alps. Differences between sites } \\
\text { insignificant }\end{array}$ \\
\hline Osadchee & $\begin{array}{l}57^{\circ} 43^{\prime} 59.22^{\prime \prime} \mathrm{E} \\
50^{\circ} 21^{\prime} 04.30^{\prime \prime} \mathrm{N}\end{array}$ & $\begin{array}{l}\text { Colony located on steep eastern slope of right bank of Oskol River (Middle } \\
\text { Pooskolye) in steppe zone. Landscape fragmented with gullies. Common } \\
\text { feather grass steppes and dry meadows with calcephyte elements and flora rep- } \\
\text { resentative of Lower Alps. Pronounced differences between sites }\end{array}$ \\
\hline $\begin{array}{l}\text { Semi-isolated population located on flat northeastern bank of Chernaya Kalitva } \\
\text { River. Common feather grass steppes with elements of Lower Alps. No differ- } \\
\text { ences between sites }\end{array}$ \\
\hline
\end{tabular}


(a)

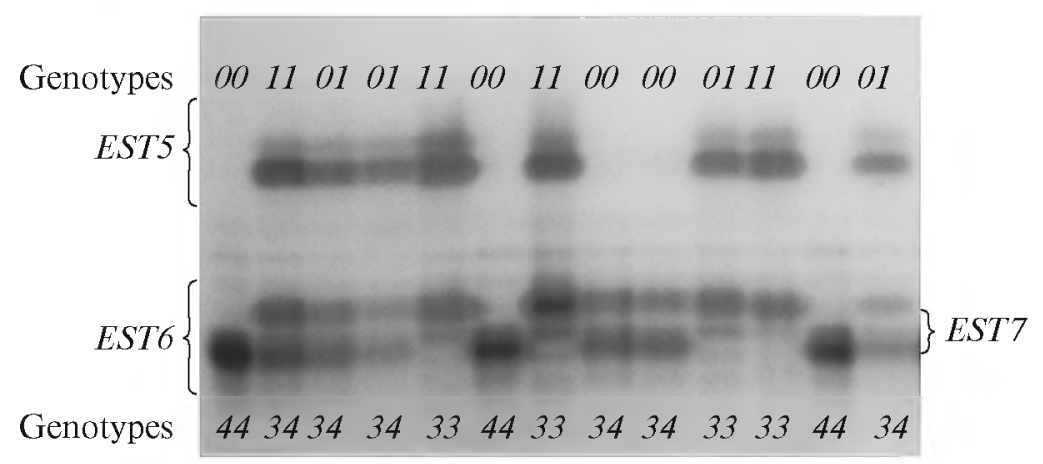

(b)

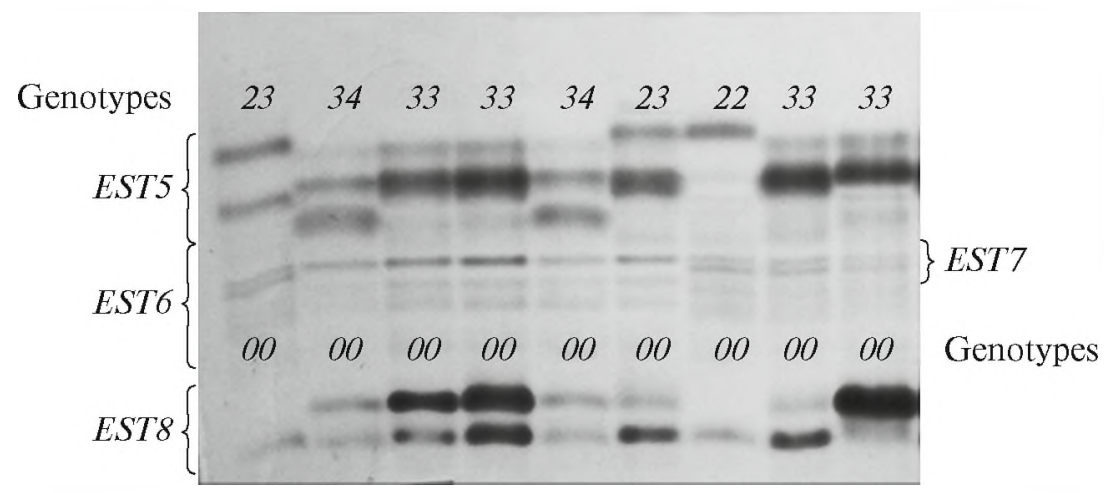

Fig. 2. Electrophoregram demonstrating presence of 0 -alleles in EST5 locus (a) in Zasosna population and EST6 locus in Belaya Gora population (b). Genotypes of individuals are listed for these loci.

dismutases, a mixture of a potassium phosphate buffer (pH 7.8), NTS, and FMS was used. Since the first publications on the genetics of $H$. striata $[10,12]$, we have obtained new data on the variability of the gene pool of the populations of this mollusk and on the nature of the allelic diversity of the allozyme loci. For example, in the previously utilized EST5 locus (nonspecific esterases), we identified the fifth allele, which has no enzyme activity (the so-called $O$-allele), and therefore its homozygotes are not identified in the gel block and heterozygotes are only present as a single band of the active allele (Fig. 2). Furthermore, the $O$-allele (also the fifth one) was detected in the EST6 locus. It was only found in the Belaya Gora population. When the 0 -allele was fixed in the population for any locus, we identified heterozygotes and homozygotes by the emerging allele according to the degree of its activity relative to other individuals. In that case, we proceeded on the principle that homozygotes are manifested more intensely on the electrophoregrams than the heterozygotes, since the concentration of the enzyme is higher in the homozygotes.

Therefore, we used four loci of nonspecific monomeric esterases (EST5 with five alleles, EST6 with five alleles, EST7 with two alleles, and EST8 with three alleles) and two loci of superoxide dismutase (SOD2 dimer with two alleles and SOD 7 monomer with three alleles) as the genetic markers of the $H$. striata population structure (Fig. 3). All alleles were inherited codominantly.

DNA was isolated using proteinase $\mathrm{K}$ and with subsequent purification with a mixture of chloroform and isopentanol $[12,20]$. ISSR amplicons of primer UBC $811\left(5^{\prime}-[\mathrm{GA}]_{8} \mathrm{C}-3^{\prime}\right)$ were used as the DNA markers. The volume of the PCR mixture was $20 \mu \mathrm{L}$; it contained $20 \mathrm{ng}$ of genomic DNA, $10 \mathrm{mM}$ of Tris $\mathrm{HCl}$ ( $\mathrm{pH} 8.3$ ), $50 \mathrm{mM}$ of $\mathrm{KCl}, 4 \mathrm{mM}$ of $\mathrm{MgCl} 2,0.25 \mathrm{mM}$ of dNTP, $0.5 \mu \mathrm{M}$ of the primer, and 1 unit of Taq DNA polymerase. The reaction was performed in a MyCycler thermocycler (BioRad, United States) under the following conditions: hot start, $2 \mathrm{~min}$ at $94^{\circ} \mathrm{C}, 40$ cycles (denaturation, $30 \mathrm{~s}$ at $94^{\circ} \mathrm{C}$; primer annealing, $30 \mathrm{~s}$ at $55^{\circ} \mathrm{C}$; synthesis, $2 \mathrm{~min}$ at $72^{\circ} \mathrm{C}$ ), additional synthesis, $10 \mathrm{~min}$ at $72^{\circ} \mathrm{C}$. The PCR products were separated by electrophoresis in $2 \%$ agarose gel using a TAE buffer, $100 \mathrm{~V}, 45 \mathrm{~min}$. The blocks were stained with ethidium bromide. Based on the pictures of electrophoresis, we comprised the binary matrices, where the presence of a band was designated by 1 (allele $p$ ) and its absence was denoted by 0 (allele $q$ ). Previously, 17 loci were isolated in $H$. striata using $U B C 811$ primers. The obtained DNA patterns and their interpretation are given in the publication of E.A. Snegin [11]. 


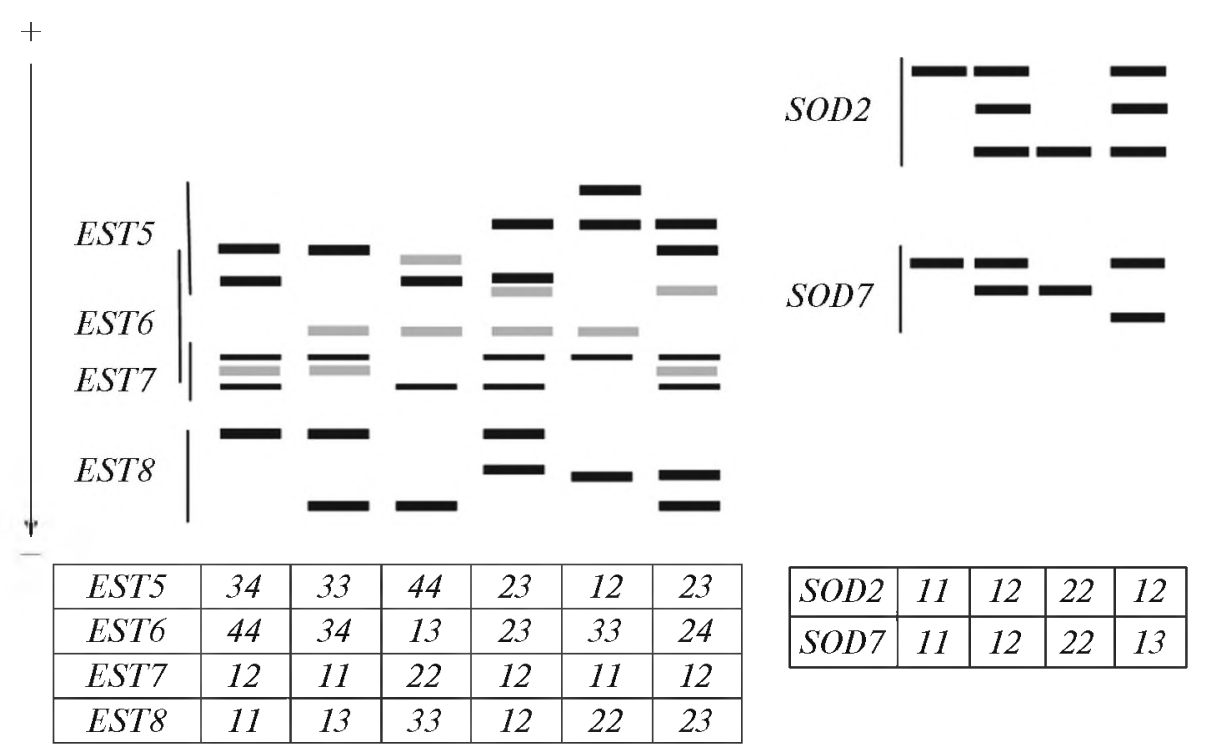

Fig. 3. Graphic image of studied allozyme loci and respective allele combinations.

In total, genotypes of $757 \mathrm{H}$. striata specimens were identified using allozymes and 701 specimens using ISSR loci.

The data were mathematically processed in the Excel (Microsoft Office), GenAlEx v 6.5 [21], and F-stat [18] software. The Debets polygons were constructed in Statistica 6.0.

\section{RESULTS AND DISCUSSION}

The Debets polygons that were constructed based on the allele frequencies of the studied isozyme loci are presented in Fig. 4.

Based on the obtained data, we find it impossible to estimate the degree of the intrapopulation structure for the Osadchee and Gubkin populations due to the absence of the variability for all the studied isozyme loci. In the remaining populations, we observed varying degrees of genetic differentiation of the demes based on the allele frequencies. For example, the frequency of the first allele EST7-1 in the Belaya Gora population comprises 0.731 in the first deme, and in the fifth deme, a hundred percent homozygosity for this allele is observed. Based on the allele SOD2-2, there are even more pronounced changes between the demes of this population: this allele was not found in the first subpopulation, while in the fifth deme, its frequency was 0.430 . Such significant changes in the allele frequencies within a single population are also observed for other loci, as well as in the other studied populations of the mollusk. In many loci, we identified the clinal or sinusoidal (which smoothly increases/decreases, then smoothly decreases/increases) variability of the allele frequencies in the populations (Fig. 5).
The obtained data suggest a low level of gene flow within the local populations.

The portion of polymorphous loci $(p)$ in demes of the populations also proved not to be constant. For example, in the Verkhnie Lubyanki population, $p$ varies from $33.3 \%$ (deme no. 4 ) to $66.7 \%$ (deme nos. 1 and 3 ). We observe significant differences between demes based both on the allele frequencies and the genetic variability indices of the individual isozyme loci.

However, based on the average values of the remaining genetic variability indices (with the exception of the inbreeding coefficient $F$ ) calculated for all loci, we found no reliable differences between demes in the populations (Table 2). Therefore, each studied population has a similar degree of genetic diversity within its distribution range, which indicates the spatial stability of the H. striata population's gene pools.

The Debets polygons constructed based on the frequencies of the $q$ allele of 17 ISSR loci in the demes of the $H$. striata populations are presented in Fig. 4. The obtained data are correlated with the variability of the allozymes. The richest gene pools are in the $H$. striata populations from the basin of the Severskii Donets River: Belaya Gora and Belenikhino, and the poorest are in Osadchee and Gubkin. Just as for allozymes, we observe significant differences in the frequencies of DNA alleles even between adjacent demes in the populations. As a result, the Debets polygons that were constructed based on the frequencies of the $q$ allele frequently differ even in the adjacent demes of a single population.

However, the general topography of the genetic variability in different sections of the distribution range of populations remains similar. For example, the average values of the genetic variability indices that 


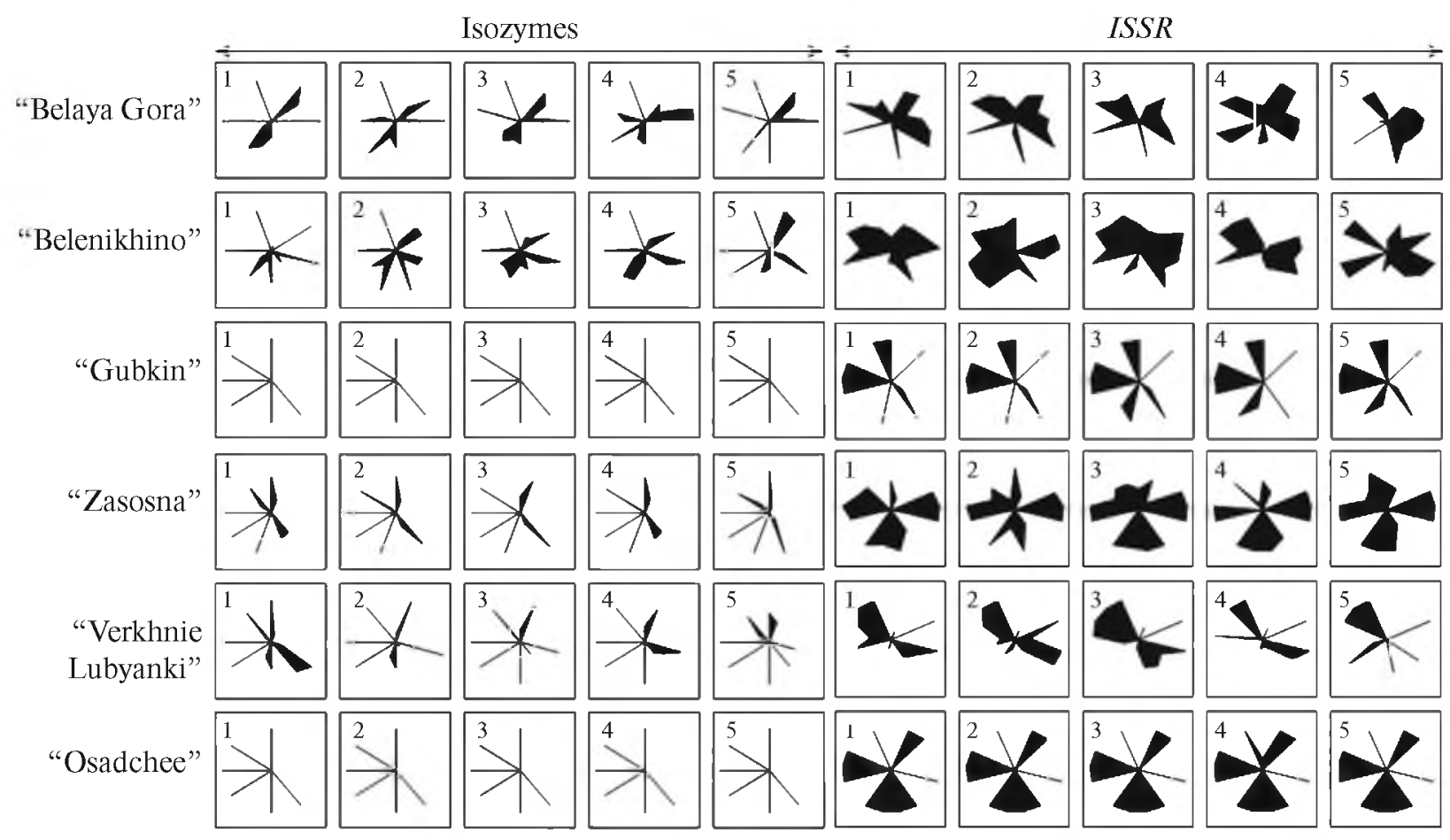

Fig. 4. Debets polygons constructed on allele frequencies of isoenzyme and ISSR loci in demes (1-5) of $H$. striata populations.

were calculated based on the ISSR loci within the populations between demes do not differ significantly, which confirms the data on the spatial stability of the intrapopulation genetic variability based on the allozymes (Table 3 ).

Based on the analysis of the allele frequencies of the isozyme loci in the studied populations, we then calculated the inbreeding coefficients for different levels of the population's hierarchy: $F_{\text {is }}, F_{\text {it }}$, and $F_{\mathrm{st}}$, as well as the subdivision index $\Phi_{\text {st }}$ (AMOVA method). We found that the studied isozyme loci make different contributions to the subdivision of populations. For example, $F_{\text {st }}$ in the Belenikhino population, which reflects the degree of population differentiation, was 0.024 for the SOD2 locus and 0.204 for the EST5 locus, i.e., almost nine times greater. Furthermore, the same loci contribute differently to the structure of different populations. For example, $F_{\text {st }}$ for the EST5 locus in different populations ranges from 0.105 in the Belaya Gora population to 0.260 in the Verkhnie Lubyanki population. This is probably due to the multidirectionality of the vectors of the selection and genetic automatic processes both in different loci and in different $H$. striata populations.

The calculation of the average values of the inbreeding indices $F_{\mathrm{st}}$ and $F_{\mathrm{it}}$ revealed a deficiency of heterozygotes for the analyzed loci in the majority of populations (Table 4).

This may indicate a low gene flow and formation of original intrapopulation groups in $H$. striata popula- tions. The calculation of the average values of the indices $F_{\text {st }}$ and $\Phi_{\text {st }}$ (Table 5) confirms these conclusions. The studied populations have different degrees of genetic dissociation between the demes. The greatest genetic structuring was found in the Verkhnie Lubyanki and Zasosna populations, which inhabit the steppe's natural zone. The degree of the biotope fragmentation of the Zasosna population is considerably lower than in the less genetically structured Belenikhino population, which indicates a different degree of migratory activity (active and passive) of $H$. striata individuals in different populations.

The values of the $\Phi_{\mathrm{st}}$ index calculated for the $I S S R$ loci (Table 6) demonstrate that the gene pool of the

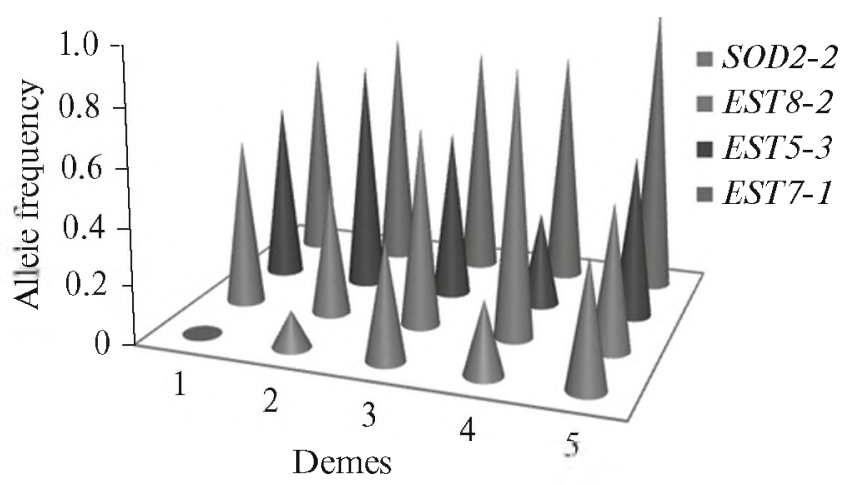

Fig. 5. Values of allele frequencies of isozyme loci in demes of Belaya Gora population. 
Table 2. Indicators of genetic variability of $H$. striata in population demes $(M \pm m)$ based on isozyme loci

\begin{tabular}{|c|c|c|c|c|c|c|c|c|c|}
\hline Population & Deme & $n$ & $p, \%$ & $A_{\mathrm{a}}$ & $A_{\mathrm{e}}$ & $I$ & $H_{\circ}$ & $H_{\mathrm{e}}$ & $F$ \\
\hline \multirow{5}{*}{$\begin{array}{c}\text { Belaya } \\
\text { Gora }\end{array}$} & 1 & 26 & 50.0 & $1.50 \pm 0.22$ & $1.42 \pm 0.19$ & $0.32 \pm 0.14$ & $0.21 \pm 0.10$ & $0.23 \pm 0.10$ & $0.09 \pm 0.10^{*}$ \\
\hline & 2 & 36 & 66.7 & $1.83 \pm 0.31$ & $1.36 \pm 0.15$ & $0.36 \pm 0.12$ & $0.22 \pm 0.08$ & $0.22 \pm 0.08$ & $0.00 \pm 0.06^{*}$ \\
\hline & 3 & 38 & 66.7 & $1.83 \pm 0.31$ & $1.57 \pm 0.21$ & $0.45 \pm 0.15$ & $0.35 \pm 0.12$ & $0.30 \pm 0.10$ & $-0.16 \pm 0.05$ \\
\hline & 4 & 34 & 66.7 & $1.83 \pm 0.31$ & $1.48 \pm 0.25$ & $0.40 \pm 0.16$ & $0.25 \pm 0.09$ & $0.24 \pm 0.10$ & $-0.05 \pm 0.07 *$ \\
\hline & 5 & 43 & 50.0 & $1.67 \pm 0.33$ & $1.54 \pm 0.25$ & $0.38 \pm 0.18$ & $0.24 \pm 0.11$ & $0.26 \pm 0.12$ & $0.05 \pm 0.04^{*}$ \\
\hline \multirow{5}{*}{ Belenikhino } & 1 & 40 & 83.3 & $2.00 \pm 0.26$ & $1.43 \pm 0.22$ & $0.38 \pm 0.15$ & $0.23 \pm 0.11$ & $0.23 \pm 0.10$ & $0.06 \pm 0.11^{*}$ \\
\hline & 2 & 39 & 83.3 & $2.33 \pm 0.42$ & $1.83 \pm 0.32$ & $0.60 \pm 0.18$ & $0.32 \pm 0.11$ & $0.37 \pm 0.11$ & $0.09 \pm 0.14^{*}$ \\
\hline & 3 & 22 & 83.3 & $2.33 \pm 0.42$ & $1.69 \pm 0.24$ & $0.57 \pm 0.16$ & $0.33 \pm 0.09$ & $0.35 \pm 0.09$ & $0.03 \pm 0.05^{*}$ \\
\hline & 4 & 40 & 66.7 & $2.17 \pm 0.31$ & $1.67 \pm 0.20$ & $0.55 \pm 0.14$ & $0.32 \pm 0.11$ & $0.35 \pm 0.09$ & $0.08 \pm 0.14^{*}$ \\
\hline & 5 & 24 & 66.7 & $2.00 \pm 0.37$ & $1.45 \pm 0.22$ & $0.39 \pm 0.17$ & $0.17 \pm 0.08$ & $0.23 \pm 0.10$ & $0.21 \pm 0.10^{*}$ \\
\hline \multirow{5}{*}{ Gubkin } & 1 & 16 & 0.0 & $1.00 \pm 0.00$ & $1.00 \pm 0.00$ & $0.00 \pm 0.00$ & $0.00 \pm 0.00$ & $0.00 \pm 0.00$ & - \\
\hline & 2 & 17 & 0.0 & $1.00 \pm 0.00$ & $1.00 \pm 0.00$ & $0.00 \pm 0.00$ & $0.00 \pm 0.00$ & $0.00 \pm 0.00$ & - \\
\hline & 3 & 19 & 0.0 & $1.00 \pm 0.00$ & $1.00 \pm 0.00$ & $0.00 \pm 0.00$ & $0.00 \pm 0.00$ & $0.00 \pm 0.00$ & - \\
\hline & 4 & 19 & 0.0 & $1.00 \pm 0.00$ & $1.00 \pm 0.00$ & $0.00 \pm 0.00$ & $0.00 \pm 0.00$ & $0.00 \pm 0.00$ & - \\
\hline & 5 & 20 & 0.0 & $1.00 \pm 0.00$ & $1.00 \pm 0.00$ & $0.00 \pm 0.00$ & $0.00 \pm 0.00$ & $0.00 \pm 0.00$ & - \\
\hline \multirow{5}{*}{ Zasosna } & 1 & 26 & 50.0 & $1.50 \pm 0.22$ & $1.38 \pm 0.18$ & $0.31 \pm 0.14$ & $0.21 \pm 0.10$ & $0.21 \pm 0.10$ & $0.02 \pm 0.08^{*}$ \\
\hline & 2 & 24 & 50.0 & $1.50 \pm 0.22$ & $1.26 \pm 0.13$ & $0.26 \pm 0.12$ & $0.15 \pm 0.08$ & $0.17 \pm 0.08$ & $0.11 \pm 0.05^{*}$ \\
\hline & 3 & 22 & 33.3 & $1.33 \pm 0.21$ & $1.24 \pm 0.15$ & $0.20 \pm 0.13$ & $0.12 \pm 0.08$ & $0.14 \pm 0.09$ & $0.12 \pm 0.02 *$ \\
\hline & 4 & 25 & 50.0 & $1.50 \pm 0.22$ & $1.29 \pm 0.17$ & $0.24 \pm 0.13$ & $0.16 \pm 0.09$ & $0.16 \pm 0.09$ & $0.00 \pm 0.01 *$ \\
\hline & 5 & 21 & 50.0 & $1.50 \pm 0.22$ & $1.20 \pm 0.10$ & $0.23 \pm 0.10$ & $0.16 \pm 0.08$ & $0.14 \pm 0.07$ & $-0.09 \pm 0.11$ \\
\hline \multirow{5}{*}{$\begin{array}{l}\text { Verkhnye } \\
\text { Lubyanki }\end{array}$} & 1 & 27 & 66.7 & $2.00 \pm 0.37$ & $1.44 \pm 0.18$ & $0.41 \pm 0.15$ & $0.23 \pm 0.08$ & $0.25 \pm 0.09$ & $0.06 \pm 0.06^{*}$ \\
\hline & 2 & 22 & 50.0 & $1.50 \pm 0.22$ & $1.24 \pm 0.14$ & $0.23 \pm 0.11$ & $0.11 \pm 0.06$ & $0.15 \pm 0.08$ & $0.27 \pm 0.06^{*}$ \\
\hline & 3 & 28 & 66.7 & $1.83 \pm 0.31$ & $1.24 \pm 0.12$ & $0.26 \pm 0.11$ & $0.12 \pm 0.06$ & $0.16 \pm 0.07$ & $0.22 \pm 0.08^{*}$ \\
\hline & 4 & 26 & 33.3 & $1.50 \pm 0.34$ & $1.27 \pm 0.17$ & $0.24 \pm 0.15$ & $0.12 \pm 0.07$ & $0.15 \pm 0.10$ & $0.23 \pm 0.01 *$ \\
\hline & 5 & 28 & 50.0 & $1.50 \pm 0.22$ & $1.43 \pm 0.20$ & $0.33 \pm 0.15$ & $0.24 \pm 0.11$ & $0.23 \pm 0.10$ & $-0.09 \pm 0.12$ \\
\hline \multirow{5}{*}{ Osadchee } & 1 & 26 & 0.0 & $1.00 \pm 0.00$ & $1.00 \pm 0.00$ & $0.00 \pm 0.00$ & $0.00 \pm 0.00$ & $0.00 \pm 0.00$ & - \\
\hline & 2 & 24 & 0.0 & $1.00 \pm 0.00$ & $1.00 \pm 0.00$ & $0.00 \pm 0.00$ & $0.00 \pm 0.00$ & $0.00 \pm 0.00$ & - \\
\hline & 3 & 23 & 0.0 & $1.00 \pm 0.00$ & $1.00 \pm 0.00$ & $0.00 \pm 0.00$ & $0.00 \pm 0.00$ & $0.00 \pm 0.00$ & - \\
\hline & 4 & 23 & 0.0 & $1.00 \pm 0.00$ & $1.00 \pm 0.00$ & $0.00 \pm 0.00$ & $0.00 \pm 0.00$ & $0.00 \pm 0.00$ & - \\
\hline & 5 & 26 & 0.0 & $1.00 \pm 0.00$ & $1.00 \pm 0.00$ & $0.00 \pm 0.00$ & $0.00 \pm 0.00$ & $0.00 \pm 0.00$ & - \\
\hline
\end{tabular}

$n$, number of individuals in dataset; ${ }^{*}$, significant deficit of heterozygotes; $A_{\mathrm{a}}$, average number of alleles in locus; $A_{\mathrm{e}}$, effective allele number in locus; $I$, Shannon index; $H_{\mathrm{o}}$, observed heterozygosity; $H_{\mathrm{e}}$, expected heterozygosity; $F$, inbreeding coefficient. Groups with monomorphic loci for which $F$ was not determined marked as line.

Verkhnie Lubyanki population is the most subdivided, and the gene pool of the Belaya Gora population ${ }^{1}$ is the least subdivided. The studied populations in general have a lower $\Phi_{\text {st }}$ value based on the $I S S R$ loci than on allozymes. This is probably due to the fact that the $I S S R$ loci mostly characterize a selectively neutral part of the genome and to a larger degree they reflect genetically automatic processes in the studied popula-

\footnotetext{
${ }^{1}$ The monomorphism of the studied genetic markers in the Osadchee population does not allow us to make conclusions on the nature of the structuring of its gene pool and the level of gene flow between demes.
}

tions. In this aspect, the degree of differentiation of the Gubkin population gene pool is notable, as it is monomorphic based on the loci of isozymes. The variability of this population based on the DNA markers was also comparatively low (only $11.76 \%$ of the loci are polymorphous). However, we found rather significant differences between demes $\left(\Phi_{\mathrm{st}}=0.206\right)$ (Table 6).

It should also be noted that the degree of subdivision of individual populations $\left(F_{\mathrm{st}} \leq 0.245 \pm 0.056\right)$ is predictably lower than the $F_{\text {st }}$ value we previously obtained for the $H$. striata of the entire Southern MidRussian Upland as a general population $\left(F_{\mathrm{st}}=0.503 \pm\right.$ 
Table 3. Average values of genetic variability in $H$. striata population demes based on DNA markers

\begin{tabular}{|c|c|c|c|c|c|c|c|}
\hline Population & Deme & $n$ & $p, \%$ & $A_{\mathrm{a}}$ & $A_{\mathrm{e}}$ & $I$ & $H_{\mathrm{e}}$ \\
\hline \multirow{5}{*}{ Belaya Gora } & 1 & 39 & 76.47 & $1.65 \pm 0.17$ & $1.52 \pm 0.09$ & $0.44 \pm 0.06$ & $0.30 \pm 0.05$ \\
\hline & 2 & 39 & 70.59 & $1.59 \pm 0.17$ & $1.52 \pm 0.10$ & $0.42 \pm 0.07$ & $0.29 \pm 0.05$ \\
\hline & 3 & 36 & 64.71 & $1.53 \pm 0.17$ & $1.50 \pm 0.10$ & $0.40 \pm 0.08$ & $0.28 \pm 0.05$ \\
\hline & 4 & 34 & 76.47 & $1.65 \pm 0.17$ & $1.57 \pm 0.10$ & $0.45 \pm 0.07$ & $0.31 \pm 0.05$ \\
\hline & 5 & 31 & 88.24 & $1.88 \pm 0.08$ & $1.59 \pm 0.09$ & $0.48 \pm 0.06$ & $0.33 \pm 0.04$ \\
\hline \multirow{5}{*}{ Belenikhino } & 1 & 24 & 76.47 & $1.65 \pm 0.17$ & $1.49 \pm 0.08$ & $0.43 \pm 0.06$ & $0.29 \pm 0.04$ \\
\hline & 2 & 24 & 70.59 & $1.59 \pm 0.17$ & $1.42 \pm 0.08$ & $0.38 \pm 0.07$ & $0.25 \pm 0.05$ \\
\hline & 3 & 21 & 70.59 & $1.53 \pm 0.19$ & $1.43 \pm 0.09$ & $0.37 \pm 0.07$ & $0.25 \pm 0.05$ \\
\hline & 4 & 24 & 70.59 & $1.59 \pm 0.17$ & $1.46 \pm 0.09$ & $0.40 \pm 0.07$ & $0.27 \pm 0.05$ \\
\hline & 5 & 24 & 82.35 & $1.71 \pm 0.17$ & $1.50 \pm 0.08$ & $0.45 \pm 0.06$ & $0.30 \pm 0.04$ \\
\hline \multirow{5}{*}{ Gubkin } & 1 & 18 & 5.88 & $0.59 \pm 0.15$ & $1.03 \pm 0.03$ & $0.03 \pm 0.03$ & $0.02 \pm 0.02$ \\
\hline & 2 & 18 & 5.88 & $0.59 \pm 0.15$ & $1.03 \pm 0.03$ & $0.03 \pm 0.03$ & $0.02 \pm 0.02$ \\
\hline & 3 & 17 & 17.65 & $0.76 \pm 0.18$ & $1.07 \pm 0.05$ & $0.07 \pm 0.04$ & $0.05 \pm 0.03$ \\
\hline & 4 & 18 & 11.76 & $0.71 \pm 0.17$ & $1.08 \pm 0.06$ & $0.07 \pm 0.05$ & $0.05 \pm 0.03$ \\
\hline & 5 & 20 & 17.65 & $0.76 \pm 0.18$ & $1.12 \pm 0.06$ & $0.10 \pm 0.06$ & $0.07 \pm 0.04$ \\
\hline \multirow{5}{*}{ Zasosna } & 1 & 23 & 52.94 & $1.24 \pm 0.22$ & $1.29 \pm 0.09$ & $0.27 \pm 0.07$ & $0.17 \pm 0.05$ \\
\hline & 2 & 25 & 52.94 & $1.24 \pm 0.22$ & $1.35 \pm 0.10$ & $0.29 \pm 0.07$ & $0.20 \pm 0.05$ \\
\hline & 3 & 21 & 47.06 & $1.06 \pm 0.23$ & $1.24 \pm 0.08$ & $0.23 \pm 0.07$ & $0.15 \pm 0.05$ \\
\hline & 4 & 23 & 35.29 & $0.88 \pm 0.22$ & $1.25 \pm 0.10$ & $0.20 \pm 0.07$ & $0.14 \pm 0.05$ \\
\hline & 5 & 17 & 41.18 & $1.00 \pm 0.23$ & $1.27 \pm 0.10$ & $0.21 \pm 0.07$ & $0.14 \pm 0.05$ \\
\hline \multirow{5}{*}{ Verknye Lubyanki } & 1 & 24 & 47.06 & $1.24 \pm 0.20$ & $1.27 \pm 0.08$ & $0.25 \pm 0.07$ & $0.17 \pm 0.05$ \\
\hline & 2 & 20 & 52.94 & $1.24 \pm 0.22$ & $1.36 \pm 0.09$ & $0.31 \pm 0.07$ & $0.21 \pm 0.05$ \\
\hline & 3 & 22 & 41.18 & $1.12 \pm 0.21$ & $1.22 \pm 0.08$ & $0.20 \pm 0.07$ & $0.13 \pm 0.05$ \\
\hline & 4 & 24 & 35.29 & $1.06 \pm 0.20$ & $1.26 \pm 0.09$ & $0.21 \pm 0.07$ & $0.15 \pm 0.05$ \\
\hline & 5 & 24 & 47.06 & $1.29 \pm 0.19$ & $1.24 \pm 0.08$ & $0.22 \pm 0.07$ & $0.14 \pm 0.05$ \\
\hline \multirow{5}{*}{ Osadchee } & 1 & 24 & 0.00 & $0.35 \pm 0.12$ & $1.00 \pm 0.00$ & $0.00 \pm 0.00$ & $0.00 \pm 0.00$ \\
\hline & 2 & 24 & 0.00 & $0.35 \pm 0.12$ & $1.00 \pm 0.00$ & $0.00 \pm 0.00$ & $0.00 \pm 0.00$ \\
\hline & 3 & 24 & 0.00 & $0.35 \pm 0.12$ & $1.00 \pm 0.00$ & $0.00 \pm 0.00$ & $0.00 \pm 0.00$ \\
\hline & 4 & 24 & 5.88 & $0.41 \pm 0.15$ & $1.03 \pm 0.00$ & $0.03 \pm 0.03$ & $0.02 \pm 0.02$ \\
\hline & 5 & 24 & 0.00 & $0.35 \pm 0.12$ & $1.00 \pm 0.00$ & $0.00 \pm 0.00$ & $0.00 \pm 0.00$ \\
\hline
\end{tabular}

Table 4. Average values of inbreeding coefficients in $H$. striata populations based on isozyme loci

\begin{tabular}{l|c|c|c}
\hline \multicolumn{1}{c|}{ Populations } & $F_{\text {is }}$ & $F_{\text {it }}$ & $F_{\text {st }}$ \\
\hline Belaya Gora & $-0.026 \pm 0.047$ & $0.082 \pm 0.046$ & $0.106 \pm 0.015$ \\
Belenikhino & $0.086 \pm 0.097$ & $0.181 \pm 0.091$ & $0.101 \pm 0.028$ \\
Zasosna & $0.013 \pm 0.038$ & $0.261 \pm 0.041$ & $0.245 \pm 0.056$ \\
Verkhnye Lubyanki & $0.080 \pm 0.067$ & $0.264 \pm 0.078$ & $0.207 \pm 0.027$ \\
\hline
\end{tabular}

$F_{\text {is }}$, inbreeding coefficient of individual relative to subpopulation; $F_{\text {it }}$, inbreeding coefficient of individual relative to large population; $F_{\text {st }}$, inbreeding coefficient of subpopulation relative to large population. Due to Gubkin and Osadchee populations being monomorphic by studied allozymes, their coefficients $F_{\mathrm{it}}, F_{\mathrm{is}}, F_{\mathrm{st}}$, and $\Phi_{\mathrm{st}}$ are absent.

0.101 ), since the gene pool of an individual population includes only a portion of the gene pool of all the populations of the mollusk from the study region. However, differentiation of the gene pools of the local
H. striata populations is higher than in many other species of terrestrial mollusks. For example, in the mesophilic mollusk Bradybaena fruticum, $F_{\text {st }}$ was 0.135 [9] in the entire Southern Mid-Russian Upland, while 
Table 5. Results of molecular variance analysis (AMOVA) in $H$. striata populations for isoenzyme loci variability

\begin{tabular}{|c|c|c|c|c|c|c|}
\hline Population & Variance & $d f$ & $S S$ & $M S$ & $E$ & $\Phi_{\mathrm{st}} ; p$ \\
\hline Belaya Gora & $\begin{array}{l}\text { Between populations } \\
\text { Within populations }\end{array}$ & $\begin{array}{r}4 \\
172\end{array}$ & $\begin{array}{r}62.757 \\
264.175\end{array}$ & $\begin{array}{r}15.689 \\
1.536\end{array}$ & $\begin{array}{l}0.402 \\
1.536\end{array}$ & $0.208(p=0.001)$ \\
\hline Belenikhino & $\begin{array}{l}\text { Between populations } \\
\text { Within populations }\end{array}$ & $\begin{array}{r}4 \\
160 \\
\end{array}$ & $\begin{array}{r}76.418 \\
330.121 \\
\end{array}$ & $\begin{array}{r}19.105 \\
2.063\end{array}$ & $\begin{array}{l}0.524 \\
2.063 \\
\end{array}$ & $0.203(p=0.001)$ \\
\hline Zasosna & $\begin{array}{l}\text { Between populations } \\
\text { Within populations }\end{array}$ & $\begin{array}{r}4 \\
113\end{array}$ & $\begin{array}{r}70.122 \\
120.633\end{array}$ & $\begin{array}{r}17.530 \\
1.068\end{array}$ & $\begin{array}{l}0.699 \\
1.068\end{array}$ & $0.396(p=0.001)$ \\
\hline Verknye Lubyanki & $\begin{array}{l}\text { Between populations } \\
\text { Within populations }\end{array}$ & $\begin{array}{r}4 \\
126\end{array}$ & $\begin{array}{r}81.799 \\
165.460\end{array}$ & $\begin{array}{r}20.450 \\
1.313\end{array}$ & $\begin{array}{l}0.732 \\
1.313\end{array}$ & $0.358(p=0.001)$ \\
\hline
\end{tabular}

$d f$, degrees of freedom; $S S$, sum of squares; $M S$, mean square; $E$, variance estimation; $p$, significance level.

Table 6. Results of AMOVA in H. striata populations based on ISSR loci

\begin{tabular}{|c|c|c|c|c|c|c|}
\hline Population & Variance & $d f$ & $S S$ & $M S$ & $E$ & $\boldsymbol{\Phi}_{\mathrm{st}} ; p$ \\
\hline Belaya Gora & $\begin{array}{l}\text { Between populations } \\
\text { Within populations }\end{array}$ & $\begin{array}{r}4 \\
174\end{array}$ & $\begin{array}{r}36.054 \\
391.510\end{array}$ & $\begin{array}{l}9.013 \\
2.250\end{array}$ & $\begin{array}{l}0.189 \\
2.250\end{array}$ & $0.078(p=0.001)$ \\
\hline Belenikhino & $\begin{array}{l}\text { Between populations } \\
\text { Within populations }\end{array}$ & $\begin{array}{r}4 \\
112\end{array}$ & $\begin{array}{r}57.632 \\
241.821\end{array}$ & $\begin{array}{r}14.408 \\
2.159\end{array}$ & $\begin{array}{l}0.524 \\
2.159\end{array}$ & $0.195(p=0.001)$ \\
\hline Gubkin & $\begin{array}{l}\text { Between populations } \\
\text { Within populations }\end{array}$ & $\begin{array}{r}4 \\
86\end{array}$ & $\begin{array}{r}5.312 \\
19.985\end{array}$ & $\begin{array}{l}1.328 \\
0.232\end{array}$ & $\begin{array}{l}0.060 \\
0.232\end{array}$ & $0.206(p=0.001)$ \\
\hline Zasosna & $\begin{array}{l}\text { Between populations } \\
\text { Within populations }\end{array}$ & $\begin{array}{r}4 \\
104\end{array}$ & $\begin{array}{r}34.424 \\
150.365\end{array}$ & $\begin{array}{l}8.606 \\
1.446\end{array}$ & $\begin{array}{l}0.330 \\
1.446\end{array}$ & $0.186(p=0.001)$ \\
\hline Verkhnie Lubyanki & $\begin{array}{l}\text { Between populations } \\
\text { Within populations }\end{array}$ & $\begin{array}{r}4 \\
109\end{array}$ & $\begin{array}{r}39.269 \\
123.942\end{array}$ & $\begin{array}{l}9.817 \\
1.137\end{array}$ & $\begin{array}{l}0.381 \\
1.137\end{array}$ & $0.251(p=0.001)$ \\
\hline Osadchee & $\begin{array}{l}\text { Between populations } \\
\text { Within populations }\end{array}$ & $\begin{array}{r}4 \\
115\end{array}$ & $\begin{array}{l}0.033 \\
0.958\end{array}$ & $\begin{array}{l}0.008 \\
0.008\end{array}$ & $\begin{array}{l}0.000 \\
0.008\end{array}$ & $0.000(p=0.100)$ \\
\hline
\end{tabular}

in the xerophilous species Chondrula tridens and Cepaea vindobonensis, $F_{\mathrm{st}}$ was 0.164 and 0.173 , respectively $[7,8]$.

Therefore, $H$. striata is characterized by one of the lowest degrees of the gene flow among the mollusks inhabiting the Southern Mid-Russian Upland. We believe that this is due to the special features of the biology of the species. $H$. striata is a stenobiontic species common in the biotopes of thoroughly warm meadows or steppe slopes $[10,12,13]$. The background mollusk species selected for the comparison are eurybiontic mesophiles or facultative xerophiles that inhabit both dry and moist biotopes [12]. It is known that snails are only active and capable of migrating in moist periods [15]. Moreover, since in the dry habitats such periods are considerably rarer than in moist habitats, $H$. striata has less total time for migration than the eurybiotic or mesophilic snail species. Furthermore, unlike some other xerophilic species, $H$. striata buries itself in the soil during droughts, due to which it becomes almost inaccessible for passive migration [1].

A low gene flow, as well as its intragroup component exceeding the intergroup one, leads to the formation of the original structured population gene pools, each of which is adapted to the local environmental conditions [2]. This organization of the genetic structure apparently allows $H$. striata to adapt to the environment of the Mid-Russian Upland's rugged landscape with its many diverse microconditions most effectively. However, the excessive specialization of the populations is accompanied by a reduction of their genetic variability and can lead to a loss of adaptive plasticity with the subsequent extinction in the case of a change in the environmental conditions. What is the more relevant for populations of the mollusk such as the Osadchee and Gubkin.

It should be noted that a significant fragmentation of the landscape is not a prerequisite for the spatial differentiation of the population gene pools into original genepools of demes. For example, the Zasosna popu- 
lation inhabits a relatively uniform biotope, lacking significant physical barriers (Table 1). Nevertheless, it has high values of $\Phi_{\text {st }}$ based on both isozymes and DNA. This is probably due to the special features of the biology of the mollusks, in particular their low mobility and confinement to the local microniches, which makes geographical distance by itself an isolating factor.

\section{CONCLUSIONS}

H. striata is characterized by a varying degree of spatial differentiation of the population's gene pools in the Southern Mid-Russian Upland. The degree of the variety of the environmental conditions is not as important for the formation of the genetic structure as the degree of individual migratory activity, which is the highest in the populations of the Severskii Donets River basin. However, the gene pools of populations of the steppe zone and Upper Pooskolye with the lowest gene flow are more isolated and it is probable that those populations are characterized by higher rates of the reduction in genetic diversity due to the greater activity of random processes. We believe that the economic use of the habitats of these groups can cause further depletion of their gene pool and subsequently their extinction.

In comparison with other studied species of the terrestrial mollusks of the Southern Mid-Russian Upland, $H$. striata is characterized by the lowest degree of gene flow. This is due to this mollusk being stenobiontic and to its lesser capability for active and passive migrations.

Furthermore, according to our data, it is necessary to consider the nature of intrapopulation spatial differentiation for obtaining a more objective picture of the state of population gene pools, since in some cases, datasets from the individual demes of the highly differentiated population might not reflect its general state.

\section{REFERENCES}

1. Balashev, I.A. and Baidashnikov, A.A., Terrestrial mollusks (Gastropoda) of the Vinnitsa oblast and their biotopic confinement, Vestn. Zool., 2012, vol. 46, no. 1, pp. 19-28.

2. Genofond i genogeografiya narodonaseleniya (The Gene Pool and Genogeography of Human Populations), Rychkov, Yu.G., Ed., St. Petersburg: Nauka, 2000.

3. Gritsenko, V.V., Ecological and genetic organization of the variability of populations of certain plant and insect species, Extended Abstract of Doctoral (Biol.) Dissertation, Kazan, 2008.

4. Kaidanov, L.Z., Genetika populyatsii (Genetics of Populations), Moscow: Vysshaya shkola, 1996.

5. Kramarenko, S.S., Analysis of intrapopulation differentiation by the example of phenetic variation of the terrestrial mollusk Brephulopsis bidens (Gastropoda: Pulmonata; Buliminidae), in Ekologo-funktsional'ni ta faunistichni aspekti doslidzhennya molyuskiv, ikh rol' $v$ bioindikatsi stanu navkolishn'ogo seredovishcha (Ecological-Functional and Faunistic Aspects of the Study of Molluscs and Their Role in Bioindication of the State of the Environment), Zhitomir: Vid. Zhitomir. Derzh. Univ. im. I. Franka, 2006, pp. 165-169.

6. Kramarenko, S.S., Formation of patterns of spatiotemporal variability of terrestrial mollusks: A multiscale approach, Extended Abstract of Doctoral (Biol.) Dissertation, 2014.

7. Snegin, E.A., The genetic structure of model species populations of terrestrial mollusks in conditions of urbanized landscape using the example of Chondrula tridens Müll (Gastropoda, Pulmonata), Russ. J. Genet.: Appl. Res., 2012, vol. 2, no. 2, pp. 160-170. doi $10.1134 / \mathrm{s} 2079059712020128$

8. Snegin, E.A., Vitality estimation of the Cepaea vindobonensis (Mollusca, Gastropoda, Pulmonata) especially protected species populations in the conditions of the Central Russian Upland forest-steppe south, Vestn. Krasnoyarsk. Gos. Agrar. Univ., 2011, no. 11, pp. 142 148.

9. Snegin, E.A., Assessment of the state of population gene pools of terestrial mollusks in conditions of influence of ore dressing combines from the example of Bradybaena fruticum Mull. (Gastropoda, Pullmonata), Russ. J. Genet.: Appl. Res., 2011, vol. 1, no. 5, pp. 379389. doi 10.1134/s2079059711050133

10. Snegin, E.A. and Sychev, A.A., Estimation of population viability of the specially protected species Helicopsis striata Müller (Mollusca, Gastropoda, Pulmonata) in Southern Mid-Russian Upland, Teor. Prikl. Ekol, 2011, no. 2, pp. 83-92.

11. Snegin, E.A., Estimating the state of population gene pools of the specially protected Helicopsis striata (Mollusca, Gastropoda, Pulmonata) species based on DNA markers, Russ. J. Genet.: Appl. Res., 2017, vol. 7, no. 2, pp. 135-144. https://doi.org/10.1134/S2079059717020113.

12. Snegin, E.A., Spatial and temporal aspects of the ecological and genetic structure of populations of invertebrates (on the example of terrestrial mollusks and insects of the south of the Central Russian Upland), Doctoral (Biol.) Dissertation, Belgorod: Belgorod State University, 2012.

13. Snegin, E.A., Helicopsis striata Müll, in Krasnaya kniga Belgorodskoi oblasti. Redkie i ischezayushchie rasteniya, griby, lishainiki i zhivotnye (The Red Book of the Belgorod Region. Rare and Endangered Plants, Fungi, Lichens, and Animals), Prisnyi, A.V., Ed., Belgorod: Belgorod. Oblastnaya Tipografiya, 2004.

14. Shvarts, S.S., Ekologicheskie zakonomernosti evolyutsii (Environmental Laws of Evolution), Moscow: Nauka, 1980.

15. Shileiko, A.A., Terrestrial mollusks of the superfamily Helicoidea, in Fauna SSSR. Mollyuski (Fauna of the USSR. Mollusks), Leningrad: Nauka, 1978, vol. 3, no. 6.

16. Arnaud, J.F., Madec, L., Bellido, A., and Guiller, A., Microspatial genetic structure in the land snail Helix aspersa (Gastropoda: Helicidae), Heredity, 1999, vol. 83, pp. 110-119. 
17. Arnaud, J.F., Madec, L., Guiller, A., and Bellido, A., Spatial analysis of allozyme and microsatellite DNA polymorphisms in the land snail Helix aspersa (Gastropoda: Helicidae), Mol. Ecol., 2001, vol. 10, pp. 15631576. doi 10.1046/j.1365-294x.2001.01292.x

18. Goudet, J., F-stat Software ver. 2.9.3.2, Lausanne: Institute of Ecology, 2002.

19. Livshits, G.M., Survival, behaviour and spatial distribution of shell morphs in a population of the snail Brephulopsis bidens (Pulmonata), Oecologia (Berlin), 1981, vol. 51, pp. 220-226.

20. Mathew, C.G., The isolation of high molecular weight eukaryotic DNA, Nucleic Acids, 1984, vol. 2, pp. 31-34.

21. Peakall, R. and Smouse, P.E., GenAlEx 6: Genetic analysis in Excel. Population genetic software for teaching and research, Mol. Ecol. Notes, 2006, vol. 6, pp. $288-295$.
22. Pfenninger, M., Relationship between microspatial population genetic structure and habitat heterogeneity in Pomatias elegans (O.F. Müller, 1774) (Caenogastropoda, Pomatiasidae), Biol. J. Linn. Soc., 2002, vol. 76, pp. $565-575$.

23. Pfenninger, M., Bahl, A., and Streit, B., Isolation by distance in a population of a small land snail Trochoidea geyeri: Evidence from direct and indirect methods, Proc. R. Soc. London B, 1996, vol. 263, no. 1374, pp. $1211-1217$.

24. Selander, R.K. and Kaufman, D.W., Genetic structure of populations of the brown snail (Helix aspersa). I. Microgeographic variation, Evolution, 1975, vol. 29, pp. 385-401.

25. Wright, S., The genetical structure of populations, Ann. Eugen., 1951, vol. 15, pp. 323-354.

Translated by $A$. Lisenkova 